\title{
Religious and Pro-Violence Populism in Indonesia: The Rise and Fall of a Far-Right Islamist Civilisationist Movement
}

\author{
Greg Barton ${ }^{1}$, Ihsan Yilmaz ${ }^{1, *(\mathbb{D})}$ and Nicholas Morieson ${ }^{2}$ (D) \\ 1 Alfred Deakin Institute for Citizenship and Globalisation, Faculty of Arts and Education, \\ Melbourne Burwood Campus, Deakin University, Melbourne 3125, Australia; greg.barton@deakin.edu.au \\ 2 Institute for Religion, Politics, and Society, Australian Catholic University, Melbourne 3065, Australia; \\ Nicholas.Morieson@acu.edu.au \\ * Correspondence: ihsan.yilmaz@deakin.edu.au
}

check for updates

Citation: Barton, Greg, Ihsan Yilmaz, and Nicholas Morieson. 2021. Religious and Pro-Violence Populism in Indonesia: The Rise and Fall of a Far-Right Islamist Civilisationist Movement. Religions 12: 397. https://doi.org/10.3390/rel12060397

Academic Editor: Enzo Pace

Received: 7 May 2021

Accepted: 24 May 2021

Published: 29 May 2021

Publisher's Note: MDPI stays neutral with regard to jurisdictional claims in published maps and institutional affiliations.

Copyright: (c) 2021 by the authors. Licensee MDPI, Basel, Switzerland. This article is an open access article distributed under the terms and conditions of the Creative Commons Attribution (CC BY) license (https:// creativecommons.org/licenses/by/ $4.0 /)$.
Abstract: The first quarter of the twenty-first century has witnessed the rise of populism around the world. While it is widespread it manifests in its own unique ways in each society, nation, and region. Religious populism, once rarely discussed, has come to take a more prominent role in the politics of a diverse range of societies and countries, as religious discourse is increasingly used by mainstream and peripheral populist actors alike. This paper examines the rise of religious populism in Indonesia through a study of the widely talked about, but little understood, Islamic Defenders Front (FPI-Front Pembela Islam). The case study method used to examine the FPI provides a unique insight into a liminal organization which, through populist and pro-violence Islamist discourse and political lobbying, has had an outsized impact on Indonesian politics. In this paper, we identify the FPI as an Islamist civilizationist populist group and show how the group frames Indonesian domestic political events within a larger cosmic battle between faithful and righteous Muslims and the forces that stand against Islam, whether they be "unfaithful Muslims" or non-Muslims. We also show how the case of the FPI demonstrates the manner in which smaller, liminal, political actors can instrumentalise religion and leverage religious rhetoric to reshape political discourse, and in doing so, drive demand for religious populism. The paper makes two arguments: First, the FPI is an example of a civilizationist populist movement which instrumentalises religion in order to create demand for its populist solutions. Second, that as Islamic groups and organisations in Indonesia increasingly rely on religio-civilizational concepts of national identity, they become more transnational in outlook, rhetoric, and organisation and more closely aligned with religious developments in the Middle East.

Keywords: populism; religious populism; civilizationism; Islamist populism; violence; far-right; Islamic Defenders Front (FPI); Indonesia; Islam

\section{Introduction}

In contrast to its previous association primarily with Latin America, in recent decades populism has been on the rise across the world in both traditionally stronger liberal democracies and politically fragile states alike. This is associated with democracy coming under pressure. Data trends from the last ten years clearly demonstrate the deteriorating quality of democracies across the world (Repucci and Slipowitz 2021; Liddiard 2019; Galston 2018a; Ginsburg et al. 2018; Pluto Journals 2017). Across a wide range of nations and political contexts, democratic institutional checks and balances have come under increased threat from illiberal and authoritarian forces. While in the past democratically elected officials, to a large extent, served to guarantee security for liberal values, the rise of once fringe populist movements into the political mainstream has led to an increasing number of violations of democracy score principles, including checks and balances on elected officials to limit the government power, the separation of powers, and guarantees of individual rights and freedoms for both the majority and minority populations (Liddiard 2019; Galston 2018b; Kyle and Mounk 2018). In today's politics, however, populism 
has become a part of both democratic and non-democratic structures, as mainstream parties and peripheral interest groups-from faith-based populist parties to environmental groups-begin to abandon liberal democratic norms for populism (Machin and Wagener 2019; Yilmaz 2021a) with an increasing willingness on the part of some to exploit overtly pro-violence rhetoric (Yilmaz and Erturk 2021).

While populism has been studied extensively, there is little scholarly agreement over its parameters. There are, however, specific conditions which most scholars agree contribute to the rise of populism within a polity. The occurrence of populism is most frequent in societies sharing the following characteristics: “(a) pre-existing religio-racial, regional or class divisions, (b) the politicisation of socioeconomic inequalities within the framework of those divisions, (c) the availability of minorities as mobilising targets for populist campaigns, and (d) the willingness of established parties to support populists in order to retain political significance" are frequent occurrences (Mietzner 2020, p. 421). Within a society afflicted with these characteristics, populism can create room for its divisive political viewpoint, which "considers society to be ultimately separated into two homogenous and antagonistic groups, 'the pure people' versus 'the corrupt elite', and which argues that politics should be an expression of the general will of the people" (Mudde 2004, p. 543). Reinforcing this simple dichotomy, populists practice a form of identity politics in which the identity of the other helps to define self-identity, or indeed, national or civilizational identity (Brubaker 2020). De Cleen and Stavrakakis furthermore argue that populism creates antagonistic relationships in two different dimensions. First, a vertical dimension in which people at the top ("elites") are distinguished from people at the bottom ("the people") of society. Second, a horizontal dimension in which "the people" are distinguished from "outsiders" based upon economic, political, ethnic, religious, or cultural differences.

Broadly speaking there are four distinctive categories used to describe the occurrence from the perspective of "ideology", "strategy", "discourse", and "style" approaches (Yilmaz and Morieson 2021; Yilmaz et al. 2021a). De Cleen and Stavrakakis (2017) argue that populism is a discourse-based occurrence that interacts with multiple factors to create two dichotomies. Kurt Weyland (2001, p. 14) views populism as "a political strategy through which a personalistic leader seeks or exercises government power based on direct, unmediated, uninstitutionalized support from large numbers of mostly unorganized followers". Moffitt (2016, p. 45) highlights the style approach referring to the "performative" side of populism in which leaders take extraordinary measures to fit in with the narrative of "the people" using language, personal style, and public appearances. A fourth group of scholars views populism as a set of ideas or ideology which asserts that the people's will is sacrosanct, and that society can be divided between "the pure people" and "the corrupt elite" (Mudde 2004, p. 543). This paper examines populism primarily through this fourth approach, which has become dominant over the past two decades of scholarship. We recognise that populism posits that a political movement, party, or especially a political leader can achieve power by claiming to be the embodiment of "the people's will", and that therefore there exists a risk that the normal checks and balances of liberal democracy will be discarded once a populist leader/movement/party has taken control of a polity (Gidron and Bonikowski 2013). In other words, in this paper we consider populism to involve an inherently illiberal set of ideas which, though they may at first appear to be harnessed in support of democratic governance if not liberal democratic norms, are in fact essentially anti-democratic and illiberal in nature and consequently often pave the way towards an authoritarian dictatorship of a single leader.

Most recent studies of populism have focused on either the transformation of mainstream parties into populist parties or on peripheral populist parties and other liminal actors becoming part of mainstream populism as political actors. In this study, the authors focus their attention on the rise and fall of the Indonesian populist Islamist and pro-violence social movement, the Islamic Defenders Front (FPI-Front Pembela Islam), and its role in influencing national and local politics as an advocacy group. The authors explore the religious populism of the FPI, its impact on domestic Indonesian politics, and the manner 
in which the religio-civilizational outlook of the FPI has pushed Indonesians to reconsider their identity within a larger transnational context and to more closely identify with the global Muslim ummah.

\section{Religion and Populism}

Proponents of the ideational approach to populism argue that populism is, at best, a "thin-centred ideology" that attaches itself to various "thick" ideologies (De Cleen and Stavrakakis 2017). By this they mean that populism is merely a loose set of ideas which requires a more comprehensive ideology to act as host. For example, populism has often been associated with or adhered to radical socialism, particularly in Latin America, where populism's insistence that society be divided between "the people" and "elites" and the people's will be obeyed combines easily and potently with socialism's call for the overthrow of economic elites and the construction of a proletarian-led society. Religion, like socialism and other comprehensive "thick" ideologies, may also be combined with populism.

Faith-based and religious identity political groups, too, have drawn on the power of populism. Religion is especially useful in driving public demand for populist political and social agendas. For example, religion and religious identity can be readily used to create exploitable divisions within society, drawing a dichotomy between "the pure people" of faith and the "evil" or "corrupt" people who are outside the circle of the faith group (Yilmaz and Morieson 2021; Mietzner 2020; Fossati and Mietzner 2019; Yilmaz et al. 2021a). Despite the common discursive use of religious identity by populists, scholarship on the subject was rare until the mid-2000s. Cas Mudde (2004) first drew attention to lack of exploration of "the relationship between religion and populist radical right parties", but the rapid rise of the far right in the global South and North led to increased scholarly interest in religious populism, particularly after the electoral breakthroughs populists began making in Europe and the United States in the mid-2010s. (Bugaric 2019; Fontana 2018; Marzouki et al. 2016; Fishkin and Forbath 2014).

One of the more important insights into the relationship between religion and populism has been that it extends, at least at times, beyond the merely functional. Thus, while there is often a hijacking of religion by populists, at times populism itself resembles a religion, "at least insofar as it sacralises 'the people' and their 'will', and promises a believing community 'salvation' if they follow a particular leader" or belong to a particular political movement (Yilmaz and Morieson 2021; Zúquete 2017, p. 446). An association with a religion offers populist leaders a unique opportunity to sacralise themselves, and to portray their political party or movement as holy, righteous, or good. Equally, by disassociating political enemies from the religion of "the people", populists can portray them as "bad", unholy, and a threat to "the pure people" and their religion.

Yilmaz and Morieson (2021) argue that it is possible to place populist movements, leaders, and parties that make religion a central element of their discourse into one of two broad categories: "religious populism" and "identitarian populism".

Religious populists are "populist leaders/parties/movements with close links to organised religion, and which have a religion-based political programme influenced by Holy Books and theology".

Narendra Modi, Recep Tayyip Erdoğan, and Imran Khan may all be considered "religious populists" insofar as they have used religious discourse to not merely construct "the people", but to actively create a more religious society in conjunction with religious authorities and/or religious organisations. Modi wears saffron to connect with the deeply religious Hindu masses through the sacred colour. Erdoğan has repeatedly used crude mannerisms dressed in religious rhetoric to take a "hard stance" on behalf of oppressed Muslims across the world. Imran Khan, in a similar manner, talks about Muslim victimhood under the pressures of Islamophobia, whilst making a show of carrying prayer beads as a sign that he is constantly seeking divine help in the midst of his "trials and tribulations" (Yilmaz 2021a; Yilmaz and Shakil 2021a, 2021b; Daragahi 2020; Osnos 2020; Iwanek 2018; Ruters 2018; Yilmaz and Bashirov 2018). 
Identitarian populists, on the other hand, are "populist leaders/parties/movements which are not influenced by theology or forms of religious spirituality but utilize the civilizational dimension of religion to identify 'the people' and their enemies according to a religion/civilisation-based classification of peoples" (Yilmaz and Morieson 2021). Identitarian populists tend to operate in more secular societies, and exploit religio-cultural divisions emerging in the West to build a more civilizationally rooted Western identity. Most often, identitarian populism in Europe takes the form of an anti-Muslim discourse, which posits that Islam and Muslims constitute an existential threat to the 'Judeo-Christian' identity of Europe and the West. This discourse is common among populists in the Netherlands, where Muslim immigrants are often held to be a threat to the "Judeo-Christian and Humanist" of the Dutch people (Morieson 2021). Equally, right-wing populists in Norway and Sweden use a similar anti-Muslim discourse rooted in the Judeo-Christian identity of the predominant population (Silva et al. 2020; Marzouki et al. 2016; Mudde 2004; Stavrakakis 2004),

Since the denouement of the Suharto regime in May 1998, religion and populism have become dominant political and social forces in Indonesia (Barton 2006, 2009, 2010, 2011, 2013, 2015a). At times they have become deeply entwined, especially in the form of the now banned, yet highly influential, Islamist populist group Islamic Defenders Front/Front Pembela Islam (FPI). This paper examines the role played by religion in the political agenda and discourse of the FPI. We show how, despite being a small group, the FPI has had a powerful impact on Indonesian politics-including on the outcome of the 2019 presidential elections-largely due to its ability to instrumentalise religion (Barton 2021). The group's populist rhetoric, which is couched within a religio-civilizational frame, has influenced aspects of Indonesian political discourse, increasing both Indonesian self-identification with Islam and the demonisation of non-Muslims, particularly ethnic Chinese.

The FPI is by no means solely responsible for the increasing importance of civilizational identity in Indonesia. Nevertheless, the rise of the FPI, first steady then rapid, and its ultimate downfall, can tell us much about the power of civilizationism in Indonesia. The FPI represents a clear example of Islamist civilizationism combined with a populist ideology. Consequently, examining the FPI helps to increase our understanding of Islamic civilizationism and populism in Indonesia. By doing so, insofar as civilizationist populism appears to be a growing phenomenon across the world, we hope to increase knowledge and understanding about civilizationist populism in general, especially the manner in which populists can harness the power of religio-civilizationism to create demand for populism.

\section{Islamist Civilizationism}

Yilmaz (2021a, pp. 136-38) defines Islamist civilizationism as a type of religious populist and Islamist rhetoric which emphasises a religio-civilizational identity in a confrontational and Manichean manner, alleging that Muslim ummah has been unjustly victimised by the domestic or foreign enemies of Islam. Indonesia's FPI is an Islamist civilizationist group which has attempted, with some success, to redefine Indonesian identity with a broader religion-based classification of civilisations. The FPI is by no means unique in this endeavour. Throughout the democratic Islamic world populism is increasingly common, and much of it possesses a discourse centred upon defining "the people" as part of a broader Islamic group, the ummah, which is in conflict with other religion-defined civilisations (e.g., the Christian West). Islamist civilizationist discourse is used not just by both extremist jihadist groups, who use it to help rationalise their violent agenda, but also by non-violent political groups, both mainstream and fringe, for whom it can help legitimise their worldview and agenda (Yilmaz et al. 2021a, 2021b; Barton 2005, 2020b).

Islamist civilizationists use Islam and Muslim civilizational identity to frame the vertical and horizontal divides typical of populism and in doing so portray the struggle between "the people" and their enemies ("elites" and "others") as part of a broader religious struggle between righteous Muslims and those outside of/hostile towards Islam (Hadiz 2018). In addition to an identity marker, Islam is often presented as a solution to 
contemporary problems. For example, Turkey's Islamist civilizationist AKP framed the country's economic and social inequalities as the result of the absence of Islam and truly Islamic rulers. In Pakistan, populist Prime Minister Imran Khan has floated the idea of "justice" delivered to the people by following the Medina model (Yilmaz and Shakil 2021a; Yilmaz and Shakil 2021b). In Indonesia, the FPI similarly promised a "moral" solution to the country's "waywardness" (Barton 2021; Yilmaz 2021a, 2021b; Aspinall and Mietzner 2019; Tomsa 2018; Tugal 2002).

Mietzner (2020, p. 425) sums up the Islamist civilizationist narrative in Indonesia: "These pious believers are victimised, in Indonesia and elsewhere, by non-Muslim or otherwise sinful forces, mostly in the West but also, increasingly, China. For the Indonesian context, this means that devout Muslims are kept away from power through an interconnected conspiracy by non-Muslim countries and Indonesian elites". Inciting intense, negative emotions in the Indonesian public by complaining of a worldwide anti-Muslim conspiracy, Indonesia's Islamist populist parties and groups attempt to position themselves as the representative of the general will of "the righteous people". This positioning allows them to claim to be saving the Indonesian people from a terrible calamity at the hands of both external and internal anti-Muslim enemies, a powerful anti-state and anti-West narrative which has helped them amass political and social power (Mietzner 2020; Peterson 2020).

While the religio-civilizational aspect of the movements, leaders, and parties associated worldwide with Islamist populism gives them the capacity to transcend nationalism and transform into truly transnational movements, the scope of almost all these movements is national. The emotive power of transnational solidarity is leveraged to serve local political interests. At the same time, Islamist civilizationists couch national identity within a broader civilizational identity, placing all Muslims ultimately within the same identity group: the Islamic ummah. For example, Yilmaz (2021a, p. 137) uses the case study of Turkey to explore Islamist civilizationism. He observes that "civilizationism is an alternative principle of vision and division of the world but it does not supersede nationalism; it is mixed with nationalism", meaning that the populisms of nationalist and religious groups blend together under this occurrence. Yilmaz $(2021 a, 2018)$ argues that AKP's promotion of neo-Ottomanist ideals through soft and hard power in various former Ottoman territories and Muslim majority countries is a revival of its legacy on transnational lines, yet one which does not attempt to destroy the primacy of Turkey as a nation-state or replace Turkish national identity with an Islam-based civilizational identity. Rather, the two inform one another, as Turkish national identity becomes determined by the civilizational identity of the citizen as an orthodox Sunni Muslim.

In addition to mainstream political actors, including democratically elected populist governments, violent extremist groups such as al-Qaeda and ISIS have also exploited the concept of civilizationism to galvanise support by pitting "the faithful" Muslim ummah against "the others" (Barton 2020a, 2020b). Al-Qaeda called upon the ummah to take up jihad against "the secular elite" within the region and "the non-Muslims" overseas (Zúquete 2017, p. 449; Barton 2005). This concept has become widely used today, but it has a longer history: Yilmaz et al. (2021a) find that, "civilisationism has been a constant part of Muslim history in the contemporary era". Populism also played a role in the pan-Islamist anti-colonial movements across Muslim societies. In South Asia, particularly in what is now Northern India, the Khilafat (Caliphate) Movement was established by the Muslims of India to "save" the dying Khilafat of the crumbling Ottoman Empire at the end of the First World War. Thousands of miles apart from the Ottoman heartland, countless Muslims volunteered in a series of civil disobedience and political lobbying acts to save the "sacred" leadership of the Caliphate, which was being dissolved by the victorious allied European forces (Pernau-Reifeld 1999; Trivedi 1981). Nearly a century later, with the revival of neo-Ottomanism by Erdoğan, the feelings of the Khilafat Movement are still very much alive within Turkey and Pakistan as the two countries are, if political rhetoric is to be 
believed, increasingly seeking to synergize their efforts in arena of trade, military, cultural, and diplomatic exchanges (Yilmaz and Shakil 2021c).

Brubaker (2017, p. 1191), in describing the civilizationism of Christian identitarian populists in Western Europe, defines an important aspect of the relationship between civilizationism and populism. He observes that populist parties in North-Western Europe define "the opposition between self and other not in narrowly national but in broader civilizational terms". Thus because "they", the enemy group, are "Muslim", "we" ("the people") are Judeo-Christian. Therefore, we may understand civilizationism among populists as something which is created, in part, in opposition to an enemy, rather than simply a self-designation. Civilizationism, then, is not something created within the confines of the nation-state, but out of a genuine sense of civilizational difference and of a clash of civilisations.

Therefore, it appears possible that populism could move beyond the nation-state and nationalism and become either transnational or ultimately international and civilizational. Indeed, Moffitt (2017, p. 421) observes that "populism can exist without nationalism, and indeed can go beyond nationalism-more so, it can also go beyond the nation-state". Moffitt's argument is reaffirmed by Yilmaz (2021a), who contends that Islamist populism can unite the ummah on civilizational lines and transcend geographical boundaries. Moreover, Islamist populism also "involves exploiting religious notions and negative emotions in the public, in order to mobilize 'public support in contests over power and resources based on an ummah-based political identity" (Yilmaz et al. 2021a). Civilizationism, here, too, is important, because it can help elicit deep emotional responses in people, including anger towards groups or individuals perceived to be insulting one's religion. Civilizationism, then, has a number of roles to play within populist discourse. In an age dominated by nation-states it is not surprising that, most often, civilizationism is subordinate to nationalism within the discourse of populists. However, in the case of Indonesia, there are signs that increasing civilizational identity is leading certain populist movements-as can be seen with the FPI - to embrace, rhetorically at least, a transnational form of politics. In the following section, this paper explores the FPI and its leadership's discourse, which presents the group as the "great leader" of Indonesian Muslims and investigates the group's engagements with civilizationism, particularly within its relationship with other Muslim countries and Islamist groups.

\section{The Role of Religion in Indonesian Politics}

\subsection{The Pre-Democracy Period}

Sukarno, a nationalist freedom fighter-turned-authoritarian populist, helped lead Indonesia to independence (Yilmaz 2020). For the next five decades the country's political landscape remained fraught, as the country transitioned from the polarising and unaccountable Sukarno regime to the even more authoritarian Suharto regime. Suharto remained in power from October 1965 until his sudden resignation in May 1998 (Barton 2002, 2013, 2015a).

While religious political parties did not exist before 1998, Islamic civil society groups such as Nahdlatul Ulama (NU), Muhammadiyah, and the Indonesian Muslim Intellectual Association (Ikatan Cendekiawan Muslim Indonesia/ICMI) played an active role in social life in Indonesia throughout the Suharto period (Nuryanti 2021). The sudden resignation of Suharto transformed Indonesian politics as the country began a transition to democracy, with Indonesian citizens allowed the liberty, for the first time in decades, to freely form political parties (Nuryanti 2021; Yilmaz 2020; Fukuoka 2013; Barton 2006, 2011, 2013, 2015a). The change allowed religious parties to form and vigorously contest for the support of voters. Along with new political parties, new advocacy groups also emerged with the aim of influencing politics without directly contesting elections. The Islamic Defenders Front/Front Pembela Islam (FPI) was one of the first of these post-Suharto Islamist activist advocacy groups to emerge. It was formed by Muhammad Rizieq Shihab in 1998, who remained active until the organisation was banned in 2020. A right-wing and ideologically 
Islamist activist group, the FPI achieved notoriety for frequent vigilante actions to "save" Islam in Indonesia from "vice" through their moral policing activities (Barton 2021; Amal 2020; Fossati and Mietzner 2019; Mietzner 2018).

Earlier Islamist groups were at times funded by the military during the final years of the Suharto regime. Although an ostensible rival, the nominally secular and non-sectarian Suharto regime used Islamist activists to attack anti-regime democracy movements and, moreover, as part of an attempt to elicit support for its own increasingly Islamic brand of Indonesian nationalism. For example, Suharto claimed that the International Monetary Fund (IMF) was an anti-Muslim existential threat to Indonesia, which deliberately sought to destabilise the country (Hadiz 2016; Sukma 1995; Anwar 1994). While Suharto's attempt to remain in power by exploiting fear ultimately failed, the Islamists would themselves soon begin to use fear to manipulate public emotions for political gain.

\subsection{Post-Democracy Period}

In the immediate post-Suharto period, the transitional Habibie presidency (1998-1999) gave space to various religious groups and their militias in order to counter growing civil unrest in the streets (Hadiz 2016, p. 154). After the fall of Suharto a raft of civil militias known as Pam Swakarsa emerged (Pam Swarkarsa is a contraction of Pasukan Pemgamnan Masyarakat Swakarsa—the Security Forces of the People's Will). Some of these Pam Swakarsa militia, formed with the support of the military elite, styled themselves as Islamist groups whilst others emphasised a nationalist identity. A number of Pam Swakarsa were deployed across Indonesia by powerful patrons to create chaos and deter anti-Habibie protesters, who were largely students in major city centres. A rebound from the years of oppression and disappointment experienced by conservative Islamic and Islamist groups in Indonesia perhaps explain why, in the 1999 general election, 20 of the 48 newly formed parties ran as Islamic parties (Adiwilaga et al. 2019, p. 434; Barton 2006, 2011, 2013, 2015a). Over time, many of these Islamic identity parties have been co-opted by the major nationalist parties, as part of an effort by both Islamists and mainstream parties to improve their chances of electoral victory (Adiwilaga et al. 2019, p. 435).

Beyond street power and political platforms, Islamic groups also found new opportunities within the politico-legal system in post-Suharto Indonesia. In particular, since the election of Susilo Bambang Yudhoyono in 2004, one of Indonesia's peak clerical bodies, the Council of Indonesian Ulama (MUI-Majelis Ulama Indonesia), has played a more overtly instrumental role in politics. The MUI was established in 1975 by the Suharto regime as an instrument of control, but in the post-Suharto era there has been a reversal of roles, with the MUI coming to be dominated by Islamist elements seeking to bend democratic politics in a more conservative direction. Having been empowered by Yudhoyono, the MUI has challenged the non-sectarian spirit of the 1945 Constitution of Indonesia, which provides a framework for establishing rule of law in accordance with liberal democratic norms on issues such as minority rights and religious freedoms. The MUI has used its position in society to proclaim national fatwa (Islamic legal opinion), which at times has been at odds with fundamental principles enshrined in the constitution. Four such controversial MUI fatwas stand out and warrant examination. While on the surface two of the fatwas are aimed at providing "protection" to the faith, in reality, these decrees have served to increase religious discrimination. For example, the MUI issued a fatwa forbidding inter-faith joint prayers and another condemning interfaith marriages. ${ }^{1,2}$ While MUI fatwas have, in the past, tended to enforce socially conservative understandings of Islam, these two rulings are substantially more controversial and interventionist, given the multi-faith nature of the Indonesian society where inter-faith activities and interactions play important roles in facilitating mutual understanding. Whilst it enjoys a high profile, the MUI does not have the authority to make its rulings legally binding for all Indonesians, and its fatwas do not necessarily represent the opinion of a majority of ulama, or indeed the Indonesian government (which is free to ignore MUI rulings), but its influence does appear to have 
grown over the past decade, and therefore we must take its fatwas seriously and consider their influence on Indonesian society.

The growing Salafi influence via the proxy of local Salafist ulama (Islamic scholars of law and theology) was clearly visible in two fatwas issued by the MUI regarding the Ahmadiyya $^{3}$ community. The MUI deemed Indonesia's Ahmadiyya community to be murtad (apostates) and has repeatedly urged the government to take action against this group by freezing their assets and implementing laws to curtail their activities. ${ }^{4}$

One of the most divisive fatwas from this period was Fatwa No. 7 of 2005 on Secularism, Pluralism, and Liberalism. This decree declared secularism, pluralism, and liberalism to be incompatible with Islam (Van Bruinessen 2013). This decree came after the induction of new radical Islamist members to the MUI (Van Bruinessen 2013). The proclamation became popularly known as the "Sepilis" fatwa. This deliberately derogatory acronym condensed secularism, pluralism, and liberalism into "sepilis" the Indonesian term for "syphilis", the sexually transmitted disease. As Van Bruinessen (2013) explains, this move was "ostensibly a frontal attack on the small group of self-defined 'liberal' Muslims of Jaringan Islam Liberal (JIL, Liberal Islam Network) centered around Ulil Abshar Abdalla but was intended to delegitimise a much broader category of Muslim intellectuals and NGO activists, including some of the most respected Muslim personalities of the previous decades".

It is also interesting to note that while the ulama wield considerable power because of their social and cultural capital, some have also delved into aligning with street protests to exert political pressure on the government. Ironically, the MUI is part of the state, yet it sees itself as a separate entity that needs to "protect" its rights from state apparatuses such as police officials. At the same time, despite its title, the Indonesian Council of Ulama is not truly representative of Indonesian ulama. It takes a very similar stance to the various right-wing parties that seek to defend Islam and themselves from "the enemy state". The strangeness of the separation of the MUI, an organ of the state, from the state itself can be seen in the creation of the Defenders of Muslim Clerics (GPU), a group formed to protect ulama from the police force (Juoro 2019, p. 28).

Because of the presence of these religious actors, the judicial system has come under pressure and been swayed by the fatwas issued by the MUI. The case of revoking the Blasphemy Law: Law 1 of 1965 on the Prevention of Abuse/Sullying of Religion in 2010 revolves around the power of Islamist populism used by the MUI and other right-wing factions to hinder the judicial process. Abdurrahman Wahid, one of Indonesia's most influential ulama, as former president and three-term head of NU, and progressive reformist (Barton 2002), led a movement to start legal proceedings to revoke the laws, which had been repeatedly misused to target non-Muslim religions (Nardi 2019; Amnesty International 2014). The attempts of Wahid and other reformist to ban the law have failed, and in less than ten years, more than 200 blasphemy cases have led to the criminal conviction of those accused (Nardi 2019). Over time, the frequency of convictions has increased drastically. This suggests that the courts, under pressure from the MUI and Islamist groups and parties, have accepted the populist narrative that "the people", Indonesia's Muslim majority, require "protection" (Lindsey 2012). The blasphemy law and its protection are a clear example of Islamist populism seeping into the legal domain and questioning the adequacy of the constitution to protect the "rights" of the majority, as they are constantly seen as "threatened" by the existence of religious minorities within the country, and by external non-Muslim forces.

\section{The Populist and Pro-Violence Islamism of the FPI}

A number of street gangs and Islamist political organisations have also been directly influenced by hard-line Wahhabism coming out of Saudi Arabia. ${ }^{5}$ The political plurality and openness of Indonesia's newly established political institutions in the 2000s provided Islamist groups, including the FPI, political space for their activities. The FPI, in particular, benefited from this hitherto unknown political openness. Founded by Muhammad Rizieq 
Shihab, the FPI is closely linked to a network of Saudi-supported religious institutes that propagate Saudi Arabian Salafi Islam across the world (Hasan 2002).

The group's core ideology is derived from their ultra-orthodox, Salafist understanding of the principles of Islam. In a political environment marred by corruption, its hard-line rhetoric and anti-establishment agenda led to significant social and political influence (Mietzner 2018). Using a populist discourse which divides society into two groups, "the people" and "others", the FPI used religious identity to determine who may be counted among "the people" and who must be excluded (Yilmaz and Barton 2021a, 2021b). The group claims Indonesia's "establishment" is un-Islamic, because it has made the Qur'an "subordinate" to the constitution. The FPI therefore calls for the implementation of a strict Sharia system in Indonesia, which would override the human made constitution and replace it with divine law (Barton 2021; Mietzner 2018; Hadiz 2016, p. 112; Wilson 2015).

The FPI's religious populism has several antecedents in Indonesian history. It leverages the fact that the whole question of the proper relationship between religion and the state remains contested and open to interpretation. As Menchik observes, the Indonesian state, despite the somewhat non-sectarian character of its constitution and founding principles, demands its citizens believe in a single God and may therefore be considered a form of-if not religious nationalism - than at least "godly nationalism" (Menchik 2014, p. 594). According to Menchik, this godly nationalism is "an imagined community bound by a common, orthodox theism and mobilized through the state in cooperation with religious organizations in society" (Menchik 2014, p. 594).

Yet even within Indonesia's godly nationalism there have always been elements-in government and society - that have pushed for a more Islamic, and especially orthodox Sunni Islamic, government and society. As Formichi points out, throughout the 1980s and 1990s the Suharto regime, partly in response to the Iranian revolution, attempted to demonise and discredit Shi'a Islam (Formichi 2014, p. 2). Beginning in 2000, and increasing after 2006, attacks on Shi'a Muslims and their places of worship and education began to occur. Sunni Muslim mobs threw stones at Shi'a and on several occasions burned down Shi'a schools and private houses (Formichi 2014, p. 1).

Formichi (2014, p. 26) explains the rise of anti-Shi'a violence in the 2000s as a consequence of the persistent othering of Shi'a by the Suharto regime and as a reaction to the loss of power Islamists experienced when the secular Megawati Sukarnoputri took power as president in 2001. She suggests that Islamists were disappointed and angered by their loss of influence, and responded by attempting to defend Islam from perceived threats, especially from non-Sunni Muslims (Formichi 2014, p. 26). During the 2000s, vigilante groups and mobs acting in the name of religion - some sanctioned by the state (Formichi 2014, p. 26) -began to stage more attacks and grow in influence. During this same period, the MUI increased in significance and, despite its fatwas not being legally binding, contributed to a growing sense of Indonesian identification with Sunni Islam. Thus, we may understand the post-Suharto period as one in which the godly nationalism of the past began to be challenged by a more narrow nationalism based on identification with orthodox Sunni Islam. This narrowing conception of Indonesian identity had the deleterious effect of turning non-Sunni Muslims into potential threats to the Indonesian state, or, as Formichi (2014, p. 27) puts it, "with the gradual strengthening of discourses of Islamic orthodoxy in the Indonesian public sphere, during the 2000s Shi'a Muslims-as well as the Ahmadis-became the new representatives of the threat to social order". Equally, it has encouraged a sense among many Sunni Muslim Indonesians that they ought to feel greater kinship with Sunni Muslims beyond their shores than with their fellow citizens who practiced other forms of religious worship.

Out of this atmosphere of increasing identification of the Indonesian state with Sunni Islam (and thus with notions of Islamic civilisation) and in which religious vigilantism was increasingly permitted by the state was born the Islamic Defenders Front. Like previous Indonesian vigilante groups that attempted to "defend" Islam from its perceived enemies, the FPI's religious convictions have led it to selectively dismiss all state authority and 
attempt to use violence and intimidation to enforce Sharia. By employing a narrative of victimhood, FPI has ensured that its "followers are kept constantly anxious about threats to their faith and way of life, and thus incentivized to hate "the Other" and at times manifest that hatred and insecurity in acts of intimidation, symbolic violence and hate speech toward out-group members" (Yilmaz and Barton 2021a). Over the years, it has acted as a vigilante group that typically mobilises younger and less-educated men, in urban and peri-urban areas, to form militia that can be mobilised to attack activities considered un-Islamic. Under the leadership of Shihab, FPI "carried out frequent acts of vigilantism under the banner of a "moral jihad" against "the Other"" (Yilmaz and Barton 2021b). It is "believed to be involved in criminal activity, including racketeering, even as they ardently oppose the presence of 'dens of vice' such as nightclubs, pubs and massage parlours" (Hadiz 2016, p. 112). Since its inception the group's members have attacked various "hot spots" in big cities, especially areas where there are night clubs and a lively atmosphere (Mietzner 2018).

The Islamic Defenders Front Militia/Front Pembela Islam or Laskar Pembela Islam (LPI) is the militant wing of the FPI. Shihab has managed "to design and organize the LPI militia in a highly systematic manner, with individuals leading paramilitary cells of various sizes just like an army" (Yilmaz and Barton 2021b). The members wear paramilitary style uniforms, carry out group attacks, and vandalize private property (Facal 2020). The organisation of the militant wing is highly militarised in terms of its hierarchical structure. A 'soldier' or member of the LPI is referred to as Jundi. From the high rank Imam, to the low rank Rais, 'officers' in the LPI can lead between 25 and 25,000 militia members.

The ultimate authority over the Jundi organisation rests in the "Grand Imam" or Imam Besar (Jahroni 2004). This military collective, along with non-militia volunteers, goes beyond merely vandalizing pre-Islamic statues and attacking "un-Islamic" venues, but has also lobbied to introduce more than 400 Shariah-inspired laws, including those that penalize adultery, force women to wear hijab head coverings, and restrict them from going out at night" (Hookway 2017). In regions where the FPI maintains strongholds, these punishments and restrictions have not only been introduced but also are widely implemented (De Haan 2020; Hookway 2017). At the same time, the FPI is not merely a vigilante group. Over the years it has taken shape as a complex organisation that carries out grassroots work by providing various welfare services such as food distribution and the schooling of young children (Hookway 2017).

The party's leaders and members have repeatedly been in trouble with law enforcement agencies. For instance, in 2003 FPI leader Muhammad Rizieq Shihab was jailed for nearly seven months (Jahroni 2004, p. 218). The group has vandalised and assaulted countless businesses and individuals over the past two decades during three-night razia raids in the name of Islam. Despite the jailing of its members, the organisation survived untillate 2020, thanks to the organisation's connections with local politicians, its ability to be used as a counter protest group, and through connections with the security forces (Facal 2020; Juoro 2019, p. 28; Mietzner 2018; Hookway 2017). An example of the alliance between politicians and the FPI is the mutual vendetta against the LGBTQ+ and Ahmadiyya communities. Exploiting the justification that it is acting to uphold Islamic morality and purity to attack these two communities, politicians seek to appease religious voters who want a more Islamic state. For the FPI, the raids were a demonstration of their populist Islamist ideology in practice: portraying themselves as defenders of "the people" and Islam, the group claimed that LGBTQ+ and Ahmadiyya people posed a threat to society, and that therefore punitive action against the groups was necessary to protect Muslims. At various instances, the police were tipped off by the FPI about gatherings of LGBTQ+ community members; at other times the FPI led rioting in villages targeting these groups while the security forces remained silent (Amal 2020, p. 585; Budiari 2018; Woodward et al. 2014).

While it is by no means the only right-wing/radical Islamist group in Indonesia, it has been observed that the FPI has been able to gain public sympathy due to its populist Islamist rhetoric, community involvement in welfare activities, and street activism in the name of Islam (Lembaga Survei Indonesia and Wahid Institute 2016). The mission of the 
group is to create an "Islamic State" or a Daulah Islam where the "common interests" of "the people" can be actualised, but radical steps have been required to achieve this. Indeed, the group's members commonly believed that a truly Islamic state was possible only if the "enemy" (non-sectarian) state apparatus was eliminated (Campbell 2017; Hookway 2017). In the FPI's vision, all Indonesians should conform to the tenants of orthodox Sunni Islam, as interpreted by Salafi ulama, leaving little room for pluralism and freedom of expression.

While the FPI is deeply involved in domestic politics, the party has also engaged the language of transnational populism. It uses the concept of civilizationism in an Islamist sense when it proclaims itself part of the struggle of the ummah or global Muslims (Nuryanti 2021; Mietzner 2018; Hadiz 2016). This trend in the formation of a consolidated identity has happened through two key factors. Firstly, various educational factions of the FPI have imparted Salafi teachings to thousands of Indonesians through their schools and provided overseas scholarships to universities in Saudi Arabia (Adiwilaga et al. 2019). Secondly, the rapid and expansive development of technology information has made it easier for Indonesian audiences to engage with content from overseas, such as viewing videos of the Rohingya massacre in Myanmar or clashes on the Gaza Strip between Palestinians and Israeli forces (Adiwilaga et al. 2019). The information flow is filtered through a Salafist framing, contributing to the dissemination of Salafism in Indonesia. This includes both non-violent Salafism and the Salafi jihadi violent extremism of al-Qaeda, ISIS and their local affiliates such as Jemaah Islamiyah (JI) and Jamaah Ansharut Daulah (JAD) (Barton 2005, 2009, 2010, 2015b, 2020a, 2020b). As a result, many Indonesians have actively participated in Islamic jihad overseas (MEI@75 2021; Idris 2018, p. 9). Both terrorist groups and Islamist groups have used technology and the exchange of students to spread the ideology.

In the case of the FPI, its formation coincides with the return of leader Muhammad Rizieq Shihab from Saudi Arabia to Indonesia. As a young scholar, Shihab won a scholarship to King Saud University to study Sharia, and he later continued his higher studies in Islam at an Organisation of the Islamic Cooperation (OIC)-sponsored university, International Islamic University, in Malaysia (Junior 2017). Over the years, Salafist literal interpretations of the Qur'an and Hadith, combined with the revolutionary Islamist ideas of Egyptian Muslim Brotherhood, have reinforced the idea that Muslims around the world have been disenfranchised and have led to the revival of the idea of a central Caliphate that would cater to the three realms of din (religion), dunya (world), and daulah (state) (Adiwilaga et al. 2019). The FPI's doctrinal orientation has meant that it frames its struggle not only against the "un-Islamic" democratic government in Indonesia but also the global "order" that the group believes to be attacking Islam. Adiwilaga et al. (2019, p. 441) call this a "new" wave of reformist populism that resonates closely with the socialist of populism from the twentieth century: "If the old populism rested on the working class or peasantry, the social basis of the new populism in the context of neoliberalism was a multi-class alliance articulated through identity as the basis of the fabric of solidarity. But most importantly, the similarity of the classical movement with the new Islamic populism that is equally continuing to undermine the discourse on dogmas 'Islam is under attack'".

The exchange of information, interactions with various cultures, and the idea of a panIslamist collective identity of victimhood has helped groups such as the FPI to galvanise support for not only a national struggle, but also for an ontological struggle of "the faithful" and "the pure" against the "malicious others". The views of Shihab are extreme when it comes to transnational populist Islamism, as over the years he has stated his admiration for the Islamic State of Iraq and the Levant (ISIL) model for the implementation of the Sharia law and called for Indonesia and other Muslim countries to follow ISIS's lead (DetikTV 2020; Barton 2015a, 2020a, 2020b). Thus, while the FPI is more of a vigilante militia, its various chapters have been linked with criminal terrorist activities in Indonesia and elsewhere (Barton 2021; WPSPOL 2018, p. 10; Campbell 2017).

The FPI's case also demonstrates the role of translational relations with fellow Muslim countries not only in terms of exchanging of ideas but also providing aid in a time of need. When Rizieq Shihab was charged with pornography offences by the Indonesian police 
in 2017, he chose to self-exile in Saudi Arabia (Aspinall and Mietzner 2019, p. 109). He spent the next few years comfortably in the country from which he telecasted his firebrand speeches at various election rallies until his return to Indonesia in 2020, when all charges were dropped against him due to inconclusive evidence (Aspinall and Mietzner 2019).

It is interesting to note that while the FPI had close ties with Saudi Arabia and the Middle East, in Indonesia, Rizieq Shihab had to merge his Islamist ideology with Indonesian nationalism when contesting the 2019 elections to ensure that his party was not seen as a vehicle of transnational Islamist populism. Given the importance of nationalism, Shihab made The Unitary State of Indonesia under Islamic Law a core part of the FPI's agenda to improve its electoral chances as it sided with the Prabowo-Sandi duo (Mietzner 2020, p. 432). One of Rizieq Shihab's Tweets from 2018 shows how Islamism and nationalism became integrated campaign ideologies, "Do you want NKRI [Indonesia] to be Syariah [sharia]? Do you want Indonesia to be blessed? Do you want the State \& Nation to be safe?" (CNN 2018).

\subsection{The Protests and the FPI}

While the FPI has condemned liberal democracies and regularly criticised democratically elected politicians for being "un-Islamic", it has certainly not remained politically isolated (Al-Battar 2013). The FPI became part of a larger hard-line collaboration in populist Islamism around Former General and now Defence Minister Prabowo Subianto, who has longbeen the recipient of Islamist support. This alliance gained further momentum during the anti-Ahok protests in 2016.

The Christian Chinese governor of Jakarta, Basuki Tjahaja Purnama-better known as Ahok-became the flashpoint for the country's Islamist civilizationist and pluralist forces in 2016 in an incident that changed the trajectory of Indonesian politics (Nuryanti 2021; Amal 2020; Adiwilaga et al. 2019; Fossati and Mietzner 2019; Mietzner 2018). Ahok belonged to the elite bourgeoisie of Jakarta, which is disproportionately dominated by ethnic Chinese, non-Muslim, and non-practicing Muslim members of the elite (Fossati and Mietzner 2019, p. 775). He was a popular deputy governor and then governor of Jakarta (becoming governor when Jokowi, the former governor, became president) and was even thought to have chance of becoming Jokowi's running mate in the 2019 general elections, with the possibility of running for the presidential office in the 2024 elections (Mietzner 2018, p. 270). Ahok's political career came to an abrupt end, however, when a heavily edited video of him speaking at a campaign rally, and citing the misuse of Qur'anic verses for political purposes by Islamist political rivals, drew fire (Nuryanti 2021). The video went viral, leading to a strong wave of anti-Ahok sentiment. A significant number of people felt Ahok had insulted the Qur'an in referring to certain verses, and the MUI issued a fatwa claiming that the governor had indeed committed blasphemy by insulting the sacred text (Nuryanti 2021; Amal 2020; Mietzner 2018). While the Jokowi government did not immediately embrace the claims, public sentiment towards Ahok hardened despite Ahok publicly apologising and clarifying that edited video excerpt was taken out of context and that he did not mean to insult Islam, Muslims, or the Qur'an (Nuryanti 2021).

Jakarta was rocked by massive protests, with hundreds of thousands taking to the streets of the national capital, in demonstrations which came to be called the Action to Defend Islam (Aksi Bela Islam) (Fealy 2016). As the name suggests, the protests used a populist Islamist narrative in which Ahok, a non-Muslim and ethnically Chinese member of the national political elite, was the centre of criticism. He became the face of "the others" that groups such as the FPI had previously attacked, both physically and verbally, thus giving a physical manifestation to the fears of "the people" that needed to defend their "pure faith" from "the outsiders", or "the elite". Fossati and Mietzner (2019) note that it was no surprise that the FPI became the face of the anti-Ahok movement with the motto "defending Islam". Rizieq Shihab positioned himself as the manifestation of the will of the people, and "[he] described himself as the "Great Leader of Indonesian Muslims", proclaiming a theologically grounded authority to voice the people's desire for a devout life 
and the removal of Islam's enemies" (Fossati and Mietzner 2019, p. 774). By December 2016, the FPI and other right-wing populist groups rode a wave of public outrage to precipitate mass rallies such as the anti-Ahok rally of 2 December 2016, in which approximately half a million people participated (Fealy 2016; Hutton 2018).

While it would be foolish to deny the influence of anti-Chinese racism in the attacks on Ahok, it is important to recognise that it was specifically the issue of blasphemy against Islam, rather than anti-Chinese sentiment, that ostensibly played the decisive role in Ahok's downfall. At the same time, it was all too easy to make accusations of blasphemy stick when the target was a Chinese Christian. Whilst many resented the idea that a Chinese Christian could be governor of Jakarta, for his rivals competing for the post of governor in the 2017 election it was more a case of political opportunism than racism.

In the anti-Ahok protests the Muslim majority became "the people" who had felt hurt and insulted by the "blasphemous" content of Ahok, thus the ummah or believers gathered en masse against the elite and otherized Ahok (Adiwilaga et al. 2019, p. 169). In a classic populist sense, according to Allan Knight (1998), the populist right-wing in Indonesia adopted the political style approach as leaders such as Rizieq Shihab became close to the people as he capitalised on "the hurt" felt by "the people". The FPI's populist discourse crossed all social lines, and through the Ahok protests the group was able to forge an "asymmetric multi-class alliance" against a single non-Muslim enemy (Adiwilaga et al. 2019; Hadiz 2016).

Eventually Ahok's reference to the use of the Qur'anic Verse 51 of Surah Al- Ma'idah ${ }^{6}$ as a political "tool" by his rivals led to him being convicted and sentenced to jail for two years under the majoritarian-driven judicial system. The protests not only led to Ahok being essentially barred from ever again holding public office in Indonesia, they also drew Jokowi closer to Islamist groups in the 2019 general elections (Yilmaz 2020). While the FPI and its leadership had always attacked Jokowi due to his moderate outlook and technocratic approach, as opposed the FPI's hard-line right-wing populism, the accusations intensified after the Ahok indecent. Before the incident Rizieq had openly described Jokowi as a "troublemaker" and "bringer of disasters" for the Muslim community, largely because he cooperated with non-Muslims. This, Rizieq said, could be the "Golden Entry Gate for non-Muslims to dominate and control the system" (Aspinall and Mietzner 2019). Thus, the Ahok incident, whilst seemly innocuous and isolated in itself, was quickly recognised by Rizieq as a battleground between his forces of Islamism on one side and the forces of liberalism and pluralism on the other, in a conflict which would determine the future of Indonesian politics and society.

\subsection{Post-Ahok Activities and Eventual Ban on the FPI}

The 2019 general elections saw the merger of the FPI with Prabowo's campaign for President of Indonesia. While the latter is not even an orthodox observant Muslim, much less a hard-line Islamist, he is a political opportunist content with using right-wing populist support to win elections. Of course, Prabowo's pragmatism must be put into context: acceptance of the Islamist civilizationist narrative by the masses forced Jokowi to re-assess his political strategy, as the previously unbeatable Ahok lost the 2017 Jakarta gubernatorial election to Anies Baswedan, a former minister of education and culture under Jokowi, but also a well-regarded Islamic intellectual opposed to non-Muslim Ahok (Amal 2020, p. 584). For the 2019 elections Jokowi settled on MUI chairman Ma'ruf Amin as his vice presidential running mate. Jokowi had been inclined to promote Mahfud MD, a popular figure within Nahdlatul Ulama and former Chief Justice of the Constitutional Court of Indonesia, as his running mate. This choice, however, was blocked by key party leaders in Jokowi's coalition, apparently because they saw the relatively young and likable Mahfud as representing a potentially tough competitor in the 2024 presidential election, when Jokowi would step aside after serving his maximum of two terms. The selection of the aged cleric Ma'ruf Amin as running mate arguably served Jokowi well in the 2019 campaign. With the head of the MUI on the ticket, any advantage that Prabowo might previously have 
enjoyed from Islamist support was neutralised. This was significant, as sectarian sentiment had taken centre stage in Indonesian politics in the wake of the anti-Ahok protests. The fearmongering of the "threat to Islam" and its synonymous intertwining with a threat to the people of Indonesia demonstrated the vulnerability of the Indonesian democracy to factors of populist Islamism and nationalism. Indonesian democracy thus came under pressure when Islamists successfully engineering a moral panic in the masses.

After the 2017 election for governor the FPI capitalised on the momentum it built during the anti-Ahok protests. But when the FPI and its partners failed in the 2019 general and presidential elections, Rizieq Shihab became the face of anti-state Islamist populism in Indonesia. After the dismissal of the 2017 charges against him, he returned to Indonesia from three years of self-imposed exile in Saudi Arabia in 2020. In the midst of the COVID-19 pandemic, Rizieq Shihab came home to bring a "moral revolution" to Indonesia (FR24 News 2020). This "moral revolution" was built of the momentum of the 2016-2017 protests that promised to "save" Islam from the threats presented by non-Muslims and non-orthodox Muslims, both in Indonesia and externally. With his hard-line Salafi allies, Rizieq Shihab amassed huge crowds clad in the FPI's iconic white clerical garb. When he returned to Jakarta, his homecoming reception saw thousands flock to the airport to welcome the "grand imam" (Maulia 2020). It can be argued that Rizieq Shihab chose a very calculated time to return to Indonesia, as anti-government sentiments ran high due to the worsening health conditions under the pandemic and the latter's ramification on the economic activities in the country (Kelemen 2021). With the country's poorest suffering most severely due to the pandemic, the FPI returned to its strongholds in rural and peri-urban regions where it had strongholds due to its community services and welfare provision for those neglected by the state (Kelemen 2021).

Flouting state regulations designed to curb the pandemic, thousands of FPI supporters gathered at rallies, in which highly controversial remarks were made attacking the Indonesian state and promoting Islamist populism. For example, in one of his speeches, while commenting on the beheading of a French schoolteacher by a Muslim upset that students had been shown cartoons satirising Islam and the Prophet Muhammad, Rizieq Shihab commented, "If they [those accused of blasphemy in Indonesia] are not investigated, don't blame Muslims if their heads are found in the streets tomorrow" (FR24 News 2020). Inciting violence, in line with the vigilantism of the group, these rallies became a concern for the Indonesian government, now struggling with surging cases of COVID-19. When the government asked the leadership of the FPI, including Rizieq Shihab, to undergo COVID-19 tests Shihab refused to attend a state-run hospital, and instead released his negative results from an Islamic hospital (Maulia 2020). The increasing support for the FPI and its "moral revolution" was, by mid-2020, presenting a clear threat to the government. Equally, it was becoming clear that Islamist populism would play a key, and potentially defining, role in the 2024 elections (Kelemen 2021).

The COVID-19 pandemic of 2020, however, proved to be the FPI's undoing. The government trace-tracked a COVID-19 cluster to FPI's unauthorized "moral revolution" FPI rallies. This gave the government an opportune excuse to neutralise the threat posed by the group, and they arrested Rizieq Shihab and imposed a ban on the FPI. The Islamist civilizationists, however, did not disappear without a fight, and in the days before the arrests and imposition of the ban the FPI leadership was able to incite its followers to resist state police forces, resulting in deadly clashes and causing a national fiasco for Jokowi, who was seen by many to be using COVID-19 as an excuse to get rid of his political opponent. Various comparisons were drawn between the events that led to the ban on the FPI and the earlier ban on Hizbut Tahrir (HTI), another hard-line Islamist group that was outlawed and dismembered by the government in 2017 (Kelemen 2021).

Since Rizieq Shihab's imprisonment, Indonesia's "moral revolution" has come to a standstill. The FPI has been banned but its ideology lives on within its many tens of thousands of supporters, and is likely to resurface in a new guise in the run up to the 
2024 elections, given the reality that religious populism has become a permanent fixture in Indonesian politics.

\section{Conclusions}

Since the end of the Suharto period Indonesia has made a remarkable transition to democracy and has consistently scored well on democratic indicators since the late 1990s (Piccone 2020; Yilmaz 2020; Bland 2019a; McWilliams 2018). The gains made on the democratic front over the last two decades, however, have been declining steadily over the past five years (Nuryanti 2021; Tehusijarana 2020; Arifianto 2019; Bland 2019b; Mietzner 2015). This decline in Indonesia's democratic measures has been caused, in part, by the growth of Islamist populism. Home to the largest Muslim population of any nation, democratic, religiously diverse Indonesia has, with its many minority religious groups, including Buddhists, Christians, Hindus, and people of Indigenous faiths, has become a battle ground for Islamist populism (Nuryanti 2021; Yilmaz 2020).

One of the primary groups that has hampered Indonesia's transition to a fully liberal democracy and a genuinely plural and tolerant society is the FPI. It is important to recognise that the banning of the group does not mean that its influence will disappear; rather, its ideas have now become pervasive and can be found across Indonesian society. The success of the movement is largely the product of its ability to channel the anger and fear felt by segments of Indonesian society within a religio-civilizational populist framing. For example, the FPI leader, Shihab, is a skilled orator who divides Indonesian society into two groups: "the pious" or "the people" who follow the FPI, and "the others": "enemies" of the faith at home such as secularists, liberals, the Ahmadiyya community, accused "blasphemers", non-Muslims, and foreign non-Muslim countries alleged to be conspiring against Muslims. He blames these groups for the failure of Indonesia's government and society to develop and create a more just polity. For Shihab, then, "the people" are not merely Indonesian citizens, they are the ummah-orthodox Muslims. Thus, the FPI has a transnational element to its populist rhetoric. This is not to say that the FPI is in fact a transnational movement. Indeed, the FPI has remained nationalist, but at the same time its religio-civilizational populism makes it look outwards, beyond Indonesia, and in doing so brings to Indonesian politics and society a sense of participation in a greater cosmic struggle between the forces of good (the ummah) and evil (non-Muslims, secular elites, blasphemers).

Religio-civilizationism is hardly unique to FPI and Indonesia. Rather, it can be found in different forms across the world, including India, Pakistan, Turkey, and even supposedly secular Western Europe, where populist parties such as France's National Rally (formerly known as the National Front) and the Dutch Party for Freedom have embraced a similar civilisation-based categorisation of peoples (Yilmaz and Morieson 2021). In the case of the National Rally, so popular has the party become that leader Marine Le Pen's civilizationist discourse, in which France is claimed to be the product of the secularisation of Christian principles incompatible with Islam (Morieson 2021, p. 133), has infiltrated mainstream French political discourse (Hellyer 2020).

The power and influence of the FPI reached a peak with the late 2016 anti-Ahok demonstrations. The FPI played a key role in convincing not only hard-liners, but also moderate Muslims, to join in the call for the ethnic Chinese and Christian former Jakarta governor to be tried and convicted for blasphemy. By "othering" Ahok, and placing him within the enemies of Islam category within a wider cosmic struggle between Muslims and non-Muslims, the FPI succeeded in creating huge rallies and ultimately pressuring the government and judicial system into convicting Ahok on spurious changes. The movement's success in removing Ahok from Indonesian politics led to them become a powerful player in the country's political life and to a close alliance with Prabowo Subianto in the 2017 gubernatorial and 2019 general elections.

While the populism of the FPI does not directly emphasise class differences, Shihab's working-class background and his simple attire reflect his populist ideology, in which he 
demands that political leaders must be one with "the people" in order to represent them in the elite world of politics. His crude kampungan (small town "red neck") language and sometimes bizarre and insensitive comments in favour of "the people" and against "the others" also reflect his populist ideas, and may be understood as an attempt to prove that he is indeed a man of the people, with the same tastes and earthy manner of speaking as the "ordinary man" or the non-elite people. In this Shihab very much follows the pattern of other Islamist populists such as Turkey's Erdogan, famous for his bombastic and vulgar stump speeches (Yilmaz 2021c; Yilmaz and Erturk 2021). Indeed, "elite" here may not refer to a specific economic class, but rather to an association with secularism and Western education. The FPI's vigilante activities are also an extension of its populist ideas. When FPI militia attack minority groups or commit other crimes, the leadership can categorise these criminal activities as necessary in a country in which "elites" have failed the people and have forced other groups to take action to prevent the moral disintegration of the country.

The popularity of the FPI and its success in influencing mainstream political discourse cannot, then, be separated from its particular religious populism. The addition of religion to populism's existing vertical and horizontal dimensions allows the FPI to categorise its allies and enemies within a larger clash of civilisations, in which Islamic civilisation is under constant attack from perceived civilizational enemies. By framing Indonesia's social and economic problems within a religio-civilizational context, the FPI can more easily create a sense of fear and crisis in the Indonesian public, emotions and thoughts that help create the demand for populism or, in this case, Islamist populism. The FPI's particular framing of economic and social injustices in Indonesia as a crisis caused by secular elites and non-Muslim internal and external enemies is designed to elicit the very emotions-particularly fear and anger-that drive the demand for Islamist populism (Yilmaz and Morieson 2021). In this way, the FPI is very similar to many other Islamist populist groups, including Turkey's ruling AKP (Yilmaz and Morieson 2021) and Pakistan's Imran Khan-led ruling Tehreek-e-Insaf (PTI) (Yilmaz et al. 2021a), two Islamist populist parties that assumed power by framing their respective nation's economy, international relations, and social problems within a religio-civilizational context in which secularist and non-Muslim forces were waging war on the ummah. Equally, the FPI's framing of Islam as the solution to the social and economic problems caused by secularism and non-Islamic governance is a common feature of Islamist populism across a range of Muslim majority democracies (Hassan 2020; Hadiz 2018).

Indonesians have enjoyed a level of political freedom in the last two decades hitherto unknown, especially during the long years of the Suharto dictatorship. This new openness has led to greater political discussion and disputation in Indonesian society, as previously prohibited voices and ideas can finally be heard. Nevertheless, the advent of open society has allowed-as it must-populist and Islamist views to be heard in public. If civil Islamic groups and secularists had been able to successfully combat these views they may not have achieved the same level of influence. The inability of successive Indonesian governments to overcome endemic corruption and economic inequality, however, has led to the rise of populist Islamist groups such as the FPI, which frame Indonesia's problems within a larger battle between the ummah and its non-Muslim and secular elite enemies. So powerful has this populist Islamist ideology become, that one of Indonesia's most prominent religious institutions, the MUI, has increasingly embraced and spread elements of the FPI's extremist beliefs. According to Peterson (2020, p. 182) "whereas MUI once comprised traditionalist and modernist ulama from NU and Muhammadiyah respectively", over time these were replaced "by reformist and puritanical ulama, with many of these reformist and puritanical ulama being affiliated with NU themselves". This is not to suggest that the MUI is today entirely composed of radical Islamists. Rather, the radicals merely appear to have the loudest voice and, at times, the greatest influence over the clerical body.

Moreover, the FPI's rise to prominence during the anti-Ahok protests not only displayed the appetite for religious populism in Indonesia, but also highlighted the power 
of peripheral right-wing groups to influence mainstream politics. For example, while President Joko Widodo-Jokowi-continues his technocratic populism, even he felt it necessary to respond to the growing power of populist Islamism in the wake of the Ahok protests. Eventually Jokowi took the bold move of banning the group. Yet while the FPI is now banned and its leader in prison, and the immediate threat the group posed to the government eliminated, the long-term threat of Islamist populism remains. Populist movements are rooted in ideas, and therefore banning them may not destroy the movements themselves, even if their leaders end up in prison. For instance, Turkey's ruling populist AKP was formed after a series of right-wing parties were banned by the Kemalist military (Yilmaz 2021a, 2021b, 2021c). While its predecessors were not able to survive, they always evolved and remerged, eventually forming the AKP, which in time became a permanent fixture in politics too powerful to be banned.

The FPI, too, cannot easily be neutralised merely by banning it. The group is an advocacy group that has succeeded in touching the lives of the most vulnerable in the poorest urban and peri-urban regions of Indonesia where the state has indeed failed the people. Once the FPI leadership is out of jail the group will likely reorganise and appear in a new form, whilst returning to grassroots community work and consolidating contact with local religious figures. It may be that the ban will ultimately serve to strengthen the FPI's contention that the state is a secularist and elitist bully that oppresses Muslims and must be overthrown, and a more Islam-based state founded in its place.

At the same time, the FPI's transnationalism may also help it to survive despite its banning. Previously, when threatened with imprisonment, Shihab sought refuge in Saudi Arabia. While he was unable to escape Indonesia on this occasion, his supporters may yet find refuge outside Indonesia, among Salafi or other hard-line Islamist groups. Even if the ban does succeed in destroying the FPI, the group has already radicalised thousands of young people through its populist ideology, and they are likely to continue responding to populist Islamist calls for vigilantism and political activism in the name of Islam.

Author Contributions: Conceptualization, I.Y., G.B. and N.M.; methodology, I.Y., G.B. and N.M. investigation, I.Y., G.B. and N.M.; resources, G.B. and I.Y.; data curation, G.B., I.Y. and N.M.; writingoriginal draft preparation, I.Y.; writing-review and editing, I.Y., N.M. and G.B.; project administration, I.Y.; internal funding acquisition, G.B. All authors have read and agreed to the published version of the manuscript.

Funding: This research received no external funding.

Conflicts of Interest: The authors declare no conflict of interest.

\section{Notes}

1 MUI Fatwa No. 3 of 2005 on Joint Prayers.

2 MUI Fatwa No. 4 of 2005 on Interfaith Marriage.

3 A sect of Islam that faces persecution by the mainstream Sunnis due to their difference over the belief regarding prophethood.

4 MUI Fatwa No. 11 of 2005 on Ahmadiyya.

5 By Islamism - an inherently imprecise term — we mean "a form of instrumentalization of Islam by individuals, groups and organizations that pursue political objectives. It provides political responses to today's societal challenges by imagining a future, the foundations for which rest on reappropriated, reinvented concepts borrowed from the Islamic tradition" (Denoeux 2002, p. 61).

6 The verses when read without context and in their literal sense mean that non-Muslims cannot become leaders over a Muslim group of people.

\section{References}

Adiwilaga, Rendy, Mustabsyirotul Ummah Mustofa, and Muhammad Ridha Taufik Rahman. 2019. Quo Vadis Islamic Populism? An Electoral Strategy. Central European Journal of International and Security Studies 13: 432-53.

Al-Battar, Saif. 2013. Habib Rizieq: Demokrasi Lebih Bahaya dari Babi. Arrahmah.com. Available online: www.arrahmah.com/news/ 2013/04/02/habib-rizieq-demokrasi-lebih-bahaya-dari-babi.html (accessed on 7 May 2021).

Amal, M. Khusna. 2020. Islamic populism in Southeast Asia: An Indonesian Muslim intellectuals perspective. Journal of Critical Reviews 7: 583-88. 
Amnesty International. 2014. Prosecuting Beliefsindonesia's Blasphemy Laws. Available online: https://www.refworld.org/pdfid/54 7593d04.pdf (accessed on 7 May 2021).

Anwar, Dewi Fortuna. 1994. Indonesia's Foreign Policy after the Cold War. Southeast Asian Affairs, 146-63. Available online: www.jstor.org/stable/27912099 (accessed on 7 May 2021). [CrossRef]

Arifianto, R. Alexander. 2019. Is Islam an Increasingly Polarizing Political Cleavage in INDONESIA? Brookings. April 25. Available online: https: / www.brookings.edu/blog/order-from-chaos/2019/04/25/is-islam-an-increasingly-polarizing-politicalcleavage-in-indonesia/ (accessed on 7 May 2021).

Aspinall, Edward, and Marcus Mietzner. 2019. Southeast Asia's Troubling Elections: Nondemocratic Pluralism in Indonesia. Journal of Democracy 30: 104-18. [CrossRef]

Barton, Greg. 2002. Abdurrahman Wahid: Muslim Democrat, Indonesian President: A View from the Inside. Sydney: UNSW Press.

Barton, Greg. 2005. Jemaah Islamiyah: Radical Islamism in Indonesia. Singapore: Singapore University Press.

Barton, Greg. 2006. Islam and Democratic Transition in Indonesia. In Religious Organizations and Democratization: Case Studies from Contemporary Asia. Edited by Deborah A. Brown and Tun-jen Cheng. New York: M.E. Sharpe, chp. 9. pp. 221-41.

Barton, Greg. 2009. The Historical Development of Jihadi Islamist Thought in Indonesia. In Radical Islamic Ideology in Southeast Asia. Edited by Scott Helfstein. New York: The Combating Terrorism Center at West Point. Available online: https://www.hsdl.org/ ?view\&did=718972 (accessed on 28 May 2021).

Barton, Greg. 2010. Indonesia. In Guide to Islamist Movements. Edited by Barry Rubin. New York: M.E. Sharpe, Inc.

Barton, Greg. 2011. Political Legitimacy in Indonesia: Islam, Democracy and Good Governance. In Political Legitimacy in Asia: New Leadership Challenges. Edited by John Kane, Hui-Chieh Loy and Haig Patapan. Palgrave Series in Asian Goverance; New York: Palgrave Macmillan.

Barton, Greg. 2013. BJ Habibie: An unlikely engineer of reform. In Democracy Take-Off? The Habibie Period. Edited by Dewi Fortuna Anwar and Bridget Welsh. Jakarta: Sinar Harapan.

Barton, Greg. 2015a. Islam and democratic transition in Indonesia. In Religious Organizations and Democratization: Case Studies from Contemporary Asia: Case Studies from Contemporary Asia. Abingdon: Routledge, pp. 221-41.

Barton, Greg. 2015b. Islamic State, Radicalisation and the Recruitment of Foreign Fighters in Australia: Making hijrah from Lucky Country to God's Nation. In Panorama_From Desert to World Cities-The New Terrorism. Singapore: Konrad Adenaeur Stiftung. Available online: https:/ / www.kas.de/en/web/politikdialog-asien/panorama/detail/- / content/from-the-desert-to-worldcities-the-new-terrorism (accessed on 7 May 2021).

Barton, Greg. 2020a. The Historical Context and Regional Social Network Dynamics of Radicalisation and Recruitment of Islamic State Foreign Terrorist Fighters in Indonesia and Its Southeast Asian Neighbours. In United by Violence, Divided by Cause: A Comparison of Drivers of Radicalisation and Violence in Asia and Europe. Edited by La Toya Waha. Baden-Baden: Nomos/KAS, pp. 117-140. Available online: https:/ / www.nomos-elibrary.de/10.5771/9783748905738.pdf (accessed on 7 May 2020).

Barton, Greg. 2020b. Salafist-jihadism in Southeast Asia. In Counterterrorism Yearbook 2020. Edited by Issac Kfir and John Coyne. Canberra: Australian Strategic Policy Institute, chp. 8. pp. 43-51. Available online: https://www.aspi.org.au/report/ counterterrorism-yearbook-2020 (accessed on 7 May 2021).

Barton, Greg. 2021. Contesting Indonesia's Democratic Transition: Laskar Jihad, the Islamic Defenders Front (FPI) and Civil Society. In Security, Democracy, and Society in Bali. Edited by Andrew Vandenberg and Nazrina Zuryani. Singapore: Palgrave Macmillan, chp. 13. pp. 305-31. Available online: https://www.springerprofessional.de/en/contesting-indonesia-s-democratic-transitionlaskar-jihad-the-is/18440394 (accessed on 7 May 2021).

Bland, Ben. 2019a. How President Joko Widodo Is Eroding Indonesia's Democracy. Italian Institute for Insertional Political Studies. Available online: https:/ / www.ispionline.it/en/pubblicazione/how-president-joko-widodo-eroding-indonesias-democracy24587 (accessed on 7 May 2021).

Bland, Ben. 2019b. The World's Most Complicated Single-Day Election Is a Feat of Democracy. The Atlantic. Available online: https://www.theatlantic.com/international/archive/2019/04/indonesias-elections-arefeat-democracy/587143/ (accessed on 7 May 2021).

Brubaker, Rogers. 2017. Between nationalism and civilizationism: The Europeans moment in comparative perspective. Ethnic and Racial Studies 40: 1191-226. [CrossRef]

Brubaker, Rogers. 2020. Populism and nationalism. Nations and Nationalism 26: 44-66. [CrossRef]

Budiari, Indra. 2018. After FPI Tipoff, Police Raid Alleged Gay Sex Party, Arrest 13. The Jakarta Post. Available online: https: //www.thejakartapost.com/news/2016/11/28/after-fpi-tipoff-police-raid-alleged-gay-sex-party-arrest-13.html (accessed on 7 May 2021).

Bugaric, Bojan. 2019. Could Populism Be Good for Constitutional Democracy? Annual Review of Law and Social Science 15: 41-58. Available online: https:/ /www.annualreviews.org/doi/abs/10.1146/annurev-lawsocsci-101518-042927 (accessed on 7 May 2021). [CrossRef]

Campbell, Charlie. 2017. ISIS Unveiled: The Story Behind Indonesia's First Female Suicide Bomber. Time. Available online: https:/ / time.com/4689714/indonesia-isis-terrorism-jihad-extremism-dian-yulia-novi-fpi/ (accessed on 7 May 2021).

CNN. 2018. Support Prabowo, Rizieq Shihab Throws the Issue of the Unitary Republic of Indonesia. CNN Indonesia. Available online: https:/ / www.cnnindonesia.com/nasional/20180917142559-32-330808/dukung-prabowo-rizieq-shihab-lempar-isunkri-bersyariah\# (accessed on 7 May 2021). 
Daragahi, Borzour. 2020. Hagia Sophia: Erdogan Recites Koran at Grand Reopening of Historic Istanbul Landmark as Mosque. The Independent. Available online: https://www.independent.co.uk/news/world/europe/hagia-sophia-reopens-mosque-erdogankoran-prayer-a9635986.html (accessed on 7 May 2021).

De Cleen, Benjamin, and Yannis Stavrakakis. 2017. Distinctions and Articulations: A Discourse Theoretical Framework for the Study of Populism and Nationalism. Javnost: The Public 24: 301-19. [CrossRef]

De Haan, Jarryd. 2020. Saudi Strategies for Religious Influence and Soft Power in Indonesia. Future Directions International. Available online: https:/ / www.futuredirections.org.au/publication/saudi-strategies-for-religious-influence-and-soft-power-in-indonesia / (accessed on 7 May 2021).

Denoeux, Guilain. 2002. The forgotten swamp: Navigating political Islam. Middle East Policy 9: 61. [CrossRef]

DetikTV. 2020. This Is the FPI Support Video to ISIS. Detik News. Available online: https://news.detik.com/detiktv/d-5314787/inivideo-dukungan-fpi-ke-isis (accessed on 7 May 2021).

Facal, Gabriel. 2020. Islamic Defenders Front Militia (Front Pembela Islam) and its Impact on Growing Religious Intolerance in Indonesia. TRaNS: Trans-Regional and-National Studies of Southeast Asia 8: 7-20. [CrossRef]

Fealy, Greg. 2016. Bigger Than Ahok: Explaining the 2 December Mass Rally. Indonesia at Melbourne. Available online: http: / / indonesiaatmelbourne.unimelb.edu.au/bigger-than-ahok-explaining-jakartas-2-december-mass-rally/ (accessed on 7 May 2021).

Fishkin, Joseph, and William E. Forbath. 2014. The Anti-Oligarchy Constitution. Boston University Law Review 94: 669.

Fontana, David. 2018. Unbundling Populism. UCLA Law Review 65: 1482.

Fossati, Diego, and Marcus Mietzner. 2019. Analyzing Indonesia's Populist Electorate. Asian Survey 59: 769-94. [CrossRef]

FR24 News. 2020. Rizieq Shihab, Back in Indonesia, Calls for “Moral Revolution”. Available online: https://www.fr24news.com/a/20 20/12/rizieq-shihab-back-inindonesia-calls-for-moral-revolution.html (accessed on 7 May 2021).

Fukuoka, Yuki. 2013. Oligarchy and Democracy in Post-Suharto Indonesia. Political Studies Review 11: 52-64. Available online: https:/ / www.researchgate.net/publication/275075301_Oligarchy_and_Democracy_in_PostSuharto_Indone (accessed on 7 May 2021). [CrossRef]

Formichi, Chiara. 2014. Violence, Sectarianism, and the Politics of Religion: Articulations of Anti-Shi'a Discourses in Indonesia. Indonesia 98: 1-27. [CrossRef]

Galston, A. William. 2018a. The Populist Challenge to Liberal Democracy. Bloomberg. Available online: https://www.brookings.edu/ research/the-populist-challenge-to-liberal-democracy/ (accessed on 7 May 2021).

Galston, A. William. 2018b. The Rise of European Populism and the Collapse of the Center-Left. Bloomberg. Available online: https:/ / www.brookings.edu/blog/order-from-chaos/2018/03/08/the-rise-of-european-populism-and-the-collapse-ofthe-center-left/ (accessed on 7 May 2021).

Gidron, Noam, and Bart Bonikowski. 2013. Varieties of Populism: Literature Review and Research Agenda. In Weatherhead Working Paper Series. No. 13-0004. Available online: https://scholar.harvard.edu/gidron/publications/varieties-populism-literaturereview-and-research-agenda (accessed on 7 May 2021).

Ginsburg, Tom, Aziz Z. Huq, and Mila Versteeg. 2018. The Coming Demise of Liberal Constitutionalism? The University of Chicago Law Review 85: 239-56. Available online: https:/ / www.jstor.org/stable/26455907 (accessed on 7 May 2021).

Hadiz, Vedi R. 2016. Islamic Populism in Indonesia and the Middle East. Cambridge: Cambridge University Press.

Hadiz, Vedi R. 2018. Imagine All the People? Mobilising Islamic Populism for Right-Wing Politics in Indonesia. Journal of Contemporary Asia 48: 566-83. [CrossRef]

Hasan, Noorhaidi. 2002. Faith and Politics: The Rise of the Laskar Jihad in the Era of Transitionin Indonesia. Indonesia 73: 145-70. [CrossRef]

Hassan, Saqlain. 2020. Populism and popularity in Imran Khan's 2018 election Speeches. In Politics and Populism across Modes and Media. Edited by Ruth Breeze and Ana María Fernández Vallejo. Bern: Peter Lang AG. Available online: https://www.researchgate.net/ publication/339336980 (accessed on 24 April 2021).

Hellyer, Hisham A. 2020. Macron's Not Worried about Islam. He's Worried about Le Pen. Foreign Policy. October 8. Available online: https:/ / foreignpolicy.com/2020/10/08/macrons-not-worried-about-islam-hes-worried-about-le-pen/ (accessed on 7 May 2021).

Hookway, James. 2017. Curfews, Obligatory Prayers, Whippings: Hard-Line Islam Emerges in Indonesia. The Wallstreet Journal. Available online: https:/ / www.wsj.com/articles/indonesia-once-a-model-of-moderate-islam-slides-toward-a-harder-line-15 05311774 (accessed on 7 May 2021).

Hutton, Jeffrey. 2018. Prabowo vs. Widodo: What Makes General Think Indonesian Election will be a Case of Second Time Lucky? South China Morning Post. Available online: http:/ / www.scmp.com/week-asia/politics/article/2136558/prabowo-vs-widodowhat-makes-general-think-indonesian-election (accessed on 7 May 2021).

Idris, Iffat. 2018. Youth Vulnerability to Violent Extremistgroups in the Indo-Pacific. GSDRC. Available online: https://gsdrc.org/wpcontent/uploads/2018/10/1438-Youth-Vulnerability-to-Violent-Extremist-Groups-in-the-Indo-Pacific.pdf (accessed on 7 May 2021).

Iwanek, Krzysztof. 2018. Paint It Saffron: The Colors of Indian Political Parties. The Diplomat. Available online: https: / / thediplomat. com/2018/09/paint-it-saffron-the-colors-of-indian-political-parties / (accessed on 7 May 2021).

Jahroni, Jajang. 2004. Depending the Majesty of Islam: Indonesia's Front Pembela Islam (FPI) 1998-2003. Studia Islamika 11. [CrossRef] 
Junior, Ibnu Umar. 2017. Biography of Habib Rizieq Shihab: Singa Allah Dari Negeri Timur: The Legend. Jakarta: Pujangga Tunggal. Juoro, Umar. 2019. The Rise of Populist Islam in Indonesia. Turkish Policy Quarterly, November 29, vol. 18, $27-33$.

Kelemen, Barbara. 2021. COVID-19 Fuels the Return of Islamism in Indonesia. MEI@75. Available online: https://www.mei.edu/ publications / covid-19-fuels-return-islamism-indonesia (accessed on 7 May 2021).

Knight, Alan. 1998. Populism and Neo-Populism in Latin America, Especially Mexico. Journal of Latin American Studies 30: $223-48$. Available online: www.jstor.org/stable/158525 (accessed on 7 May 2021).

Kyle, Jordan, and Yascha Mounk. 2018. The Populist Harm to Democracy: An Empirical Assessment. Tony Blair Institute for Global Change. Available online: https://institute.global/policy/populist-harm-democracy-empirical-assessment (accessed on 7 May 2021).

Lembaga Survei Indonesia and Wahid Institute. 2016. The Potential of Radicalism and Socio-Religious Intolerance among Indonesian Muslims. Jakarta: LSI.

Liddiard, Patrick. 2019. Is Populism Really a Problem for Democracy? Occasional Paper. Washington, DC: Wilson Center. Available online: https:/ / www.wilsoncenter.org/sites/default/files/media/documents/publication/liddiard_is_populism_really_a_ problem_for_democracy_august_2019_0.pdf (accessed on 7 May 2021).

Lindsey, Tim. 2012. Monopolising Islam: The Indonesian Ulama Council and state regulation of the 'Islamic economy'. Bulletin of Indonesian Economic Studies 48: 253-74. [CrossRef]

Machin, Amanda, and Oliver Wagener. 2019. The Nature of Green Populism? Green European Journal. February 22. Available online: https:/ / www.greeneuropeanjournal.eu/the-nature-of-green-populism/ (accessed on 7 May 2021).

Marzouki, Nadia, Duncan McDonnell, and Olivier Roy. 2016. Saving the People: How Populists Hijack Religion. London: Hurst \& Company. Available online: http:/ / hdl.handle.net/1814/43166 (accessed on 7 May 2021).

Maulia, Erwida. 2020. Indonesian Firebrand Cleric Habib Rizieq Faces Arrest in Jakarta. Nikkei Asia. Available online: https: / / asia.nikkei.com/Spotlight/Islam-in-Asia/Indonesian-firebrand-cleric-Habib-Rizieq-faces-arrest-in-Jakarta (accessed on 7 May 2021).

McWilliams, Edmund. 2018. On the 20th Anniversary of Its Democratic Experiment, Indonesia Can Cite Significant Gains. Growing Challenges May Threaten That Progress. Foreign Service Journal. Available online: https://www.afsa.org/democracy-indonesiaprogress-report (accessed on 7 May 2021).

MEI@75. 2021. Jihadi Recruitment and Return: Asian Threat and Response. Available online: https:/ /www.mei.edu/publications / jihadi-recruitment-and-return-asian-threat-and-response (accessed on 7 May 2021).

Menchik, Jeremy. 2014. Productive Intolerance: Godly Nationalism in Indonesia. Comparative Studies in Society and History 56: 591-621. [CrossRef]

Mietzner, Marcus. 2015. Reinventing Asian Populism: Jokowi's Rise, Democracy, and Political Contestation in Indonesia. Honolulu: East-West Center.

Mietzner, Marcus. 2018. Fighting Illiberalism with Illiberalism: Islamist Populism and Democratic Deconsolidation in Indonesia. Pacific Affairs 91: 261-82. [CrossRef]

Mietzner, Marcus. 2020. Rival populisms and the democratic crisis in Indonesia: Chauvinists, Islamists and technocrats. Australian Journal of International Affairs 74: 420-38. [CrossRef]

Moffitt, Benjamin. 2016. The Global Rise of Populism: Performance, Political Style, and Representation. Palo Alto: Stanford UP.

Moffitt, Benjamin. 2017. Transnational Populism? Representative Claims, Media and the Difficulty of Constructing a Transnational "People". Javnost-The Public 24: 409-25. [CrossRef]

Morieson, Nicholas. 2021. Religion and the Populist Radical Right: Secular Christianism and Populism in Western Europe. Delaware and Malaga: Vernon Press.

Mudde, Cas. 2004. The Populist Zeitgeist. Government and Opposition. Government and Opposition 39: 541-63. [CrossRef]

Nardi, J. Dominic. 2019. Policy Update: Blasphemy Allegationsin a Polarized Indonesia. United States Commission on International Religious Freedoms. Available online: https:/ / www.uscirf.gov/sites/default/files/2019\%20Indonesia\%20blasphemy.pdf (accessed on 7 May 2021).

Nuryanti, Sri. 2021. Populism in Indonesia: Learning from the 212 Movement in Response to the Blasphemy Case against Ahok in Jakarta. In Populism in Asian Democracies. Edited by Sook Jong Lee, Chin-en Wu and Kaustuv Kanti Bandyopadhyay. Boston: Brill.

Osnos, Evan. 2020. An Abuse of Sacred Symbols: Trump, a Bible, and a Sanctuary. The New Yorker. Available online: https: //www.newyorker.com/news/daily-comment/an-abuse-of-sacred-symbols-trump-a-bible-and-a-sanctuary (accessed on 7 May 2021).

Pernau-Reifeld, Margrit. 1999. Reaping the Whirlwind: Nizam and the Khilafat Movement. Economic and Political Weekly 34: $2745-51$.

Peterson, Daniel. 2020. Islam, Blasphemy, and Human Rights in Indonesia: The Trial of Ahok. London: Routledge.

Piccone, Ted. 2020. Democracy the Indonesian Way. Brookings. Available online: https://www.brookings.edu/blog/up-front/2010/0 4/22/democracy-the-indonesian-way/ (accessed on 7 May 2021).

Pluto Journals. 2017. The Rise of Authoritarian Populism in the 21st Century: From Erdoğan's Turkey to Trump's America. Journal of Global Faultines 4: 3-6. [CrossRef]

Repucci, Sarah, and Amy Slipowitz. 2021. Freedom in the World 2021: Democracy under Siege. Freedom House. Available online: https:/ / freedomhouse.org/report/freedom-world/2021/democracy-under-siege (accessed on 7 May 2021). 
Ruters. 2018. Pakistan's Imran Khan Quietly Confident He Will Be PM. Arab News. Available online: https:/ /www.arabnews.com/ node/1338391/world (accessed on 7 May 2021).

Silva, Jason R., Celinet Duran, Joshua D. Freilich, and Steven M. Chermak. 2020. Addressing the Myths of Terrorism in America. International Criminal Justice Review 30: 302-24. [CrossRef]

Stavrakakis, Yannis. 2004. Antinomies of formalism: Laclau's theory of populism and the lessons from religious populism in Greece. Journal of Political Ideologies 9: 253-67. [CrossRef]

Sukma, Rizal. 1995. The Evolution of Indonesia's Foreign Policy: An Indonesian View. Asian Survey 35: 304-15. Available online: www.jstor.org/stable/2645547 (accessed on 7 May 2021). [CrossRef]

Tehusijarana, M. Karina. 2020. Indonesia, Once Regional Model, Falls behind Malaysia in Democracy Ranking. The Jakarta Post. Available online: https:/ / www.thejakartapost.com/seasia/2020/01/22/2019-eiu-democracy-index-shows-indonesia-fallingfurther-behind-malaysia.html (accessed on 7 May 2021).

Tomsa, Dirk. 2018. Regime Resilience and Presidential Politics in Indonesia. Contemporary Politics 24: 266-85. [CrossRef]

Trivedi, Raj Kumar. 1981. Mustafa Kemal and the Indian Khilafat Movement (to 1924). Proceedings of the Indian History Congress 42: 458-67.

Tugal, Cihan. 2002. Islamism in Turkey: Beyond instrument and meaning. Economy and Society 31: 85-111. [CrossRef]

Van Bruinessen, Martin. 2013. Contemporary Developments in Indonesian Islam: Explaining the "Conservative Turn". Singapore: ISEASYusof Ishak Institute.

Weyland, Kurt. 2001. Clarifying a Contested Concept: Populism in the Study of Latin American Politics. Comparative Politics 34: 1-22. Available online: www.jstor.org/stable/422412 (accessed on 7 May 2021). [CrossRef]

Wilson, Ian. 2015. The Politics of Protection Rackets in Post-New Order Indonesia: Coercive Capital, Authorityand Street Politics. London: Routledge.

Woodward, Mark, Mariani Yahya, Inayah Rohmaniyah, Diana Murtaugh Coleman, Chris Lundry, and Ali Amin. 2014. The Islamic Defenders Front: Demonization, Violence and the State in Indonesia. Cont Islam 8: 153-71. [CrossRef]

WPSPOL. 2018. The Current State of Terrorism in Indonesia: Vulnerable Groups, Networks, and Responses. Jakarta: Centre for Strategic and International Studies. Available online: https://csis.or.id/uploaded_file/publications/the_current_state_of_terrorism_in_ indonesia___vulnerable_groups_networks_and_responses.pdf (accessed on 7 May 2021).

Yilmaz, Ihsan. 2018. Islamic Populism and Creating Desirable Citizens in Erdogan's New Turkey. Mediterranean Quarterly $29:$ 52-76. [CrossRef]

Yilmaz, Ihsan. 2020. Populism Profile: Indonesia. European Center for Populism Studies. Available online: https://www. populismstudies.org/tag/indonesia/ (accessed on 7 May 2021).

Yilmaz, Ihsan. 2021a. Creating the Desired Citizens: State, Islam and Ideology in Turkey. Cambridge and New York: Cambridge University Press.

Yilmaz, Ihsan. 2021b. The AKP's Authoritarian, Islamist Populism: Carving out a New Turkey. ECPS. Available online: https: //www.populismstudies.org/the-akps-authoritarian-islamist-populism-carving-out-a-new-turkey (accessed on 7 May 2021).

Yilmaz, Ihsan. 2021c. Erdogan's Political Journey: From Victimised Muslim Democrat to Authoritarian, Islamist Populist. ECPS. Available online: https:/ / www.populismstudies.org/erdogans-political-journey-from-victimised-muslim-democrat-to-authoritarianislamist-populist/ (accessed on 7 May 2021).

Yilmaz, Ihsan, and Greg Barton. 2021a. Islamic Defenders Front: The Face of Indonesia's Far-Right Islamism. ECPS. Available online: https: / / www.populismstudies.org/the-islamic-defenders-front-the-face-of-indonesias-far-right-islamism/ (accessed on 7 May 2021).

Yilmaz, Ihsan, and Greg Barton. 2021b. Populism, Violence, and Vigilantism in Indonesia: Rizieq Shihab and His Far-Right Islamist Populism. ECPS. Available online: https:/ / www.populismstudies.org/populism-violence-and-vigilantism-in-indonesia-rizieqshihab-and-his-far-right-islamist-populism/ (accessed on 7 May 2021).

Yilmaz, Ihsan, and Galib Bashirov. 2018. The AKP after 15 years: Emergence of Erdoganism in Turkey. Third World Quarterly 39: 1812-30. [CrossRef]

Yilmaz, Ihsan, and Omer F. Erturk. 2021. Populism, Violence and Authoritarian Stability: Necropolitics in Turkey. Third World Quarterly, 1-20. [CrossRef]

Yilmaz, Ihsan, and Nicholas Morieson. 2021. A Systematic Literature Review of Populism, Religion and Emotions. Religions 12: 272. [CrossRef]

Yilmaz, Ihsan, and Kainat Shakil. 2021a. Pakistan Tehreek-e-Insaf: Pakistan's IconicPopulist Movement. ECPS. Available online: https:/ / www.populismstudies.org/pakistan-tehreek-e-insaf-pakistans-iconic-populist-movement/ (accessed on 7 May 2021).

Yilmaz, Ihsan, and Kainat Shakil. 2021b. Imran Khan: From Cricket Batsman to Populist Captain Tabdeli of Pakistan. ECPS. Available online: https:/ / www.populismstudies.org/imran-khan-from-cricket-batsman-to-populist-captain-tabdeli-of-pakistan/ (accessed on 7 May 2021).

Yilmaz, Ihsan, and Kainat Shakil. 2021c. Transnational Islamist Populism between Pakistan and Turkey: The Case of Dirilis—Ertugrul. European Center for Populism Studies. Available online: https://www.populismstudies.org/transnational-islamist-populismbetween-pakistan-and-turkey-the-case-of-dirilis-ertugrul/ (accessed on 7 May 2021).

Yilmaz, Ihsan, Nicholas Morieson, and Mustafa Demir. 2021a. Exploring Religions in Relation to Populism: A Tour around the World. Religions 12: 301. [CrossRef] 
Yilmaz, Ihsan, Mustafa Demir, and Nicholas Morieson. 2021b. Religion in Creating Populist Appeal: Islamist Populism and Civilizationism in the Friday Sermons of Turkey's Diyanet. Religions 12: 359. [CrossRef]

Zúquete, Jose Pedro. 2017. Populism and Religion. In The Oxford Handbook of Populism. Edited by Cristóbal Rovira Kaltwasser, Paul Taggart, Paulina Ochoa Espejo and Pierre Ostiguy. Oxford: Oxford University Press. 